\title{
Character Education at MAN 3 Palembang Boarding School
}

\author{
Revki Rama Delvi \\ Graduate School \\ Universitas Negeri Yogyakarta \\ Yogyakarta, Indonesia \\ revki.rama2016@student.uny.ac.id
}

\author{
Saefur Rochmat \\ Graduate School \\ Universitas Negeri Yogyakarta \\ Yogyakarta, Indonesia \\ saefur_rochmat@uny.ac.id
}

\begin{abstract}
This study aims to describe the application of character-building values in Palembang MAN 3 dorm. This study uses qualitative research methods with the kind of case studies conducted in MAN 3 Palembang. Data collection techniques used in this study are observation, interviews and documentation. The validity of the data is done by technical triangulation and triangulation of supporting reference data sources. Data analysis techniques uses field notes, data reduction, data presentation, data verification. The results of this study show that the dormitory of the MAN 3 Palembang has implemented character building based on religious values and independence. Leadership, independence and religion of this program are put together from the dormitory in accordance with the needs in the sense that the program is flexible. Boarding schools get used to everyday life in order to teach their students the value of their independence. Activities like these are always carried out in daily life, starting with the dormitory activities, learning and returning to the dormitory. Boarding Education System provides student dormitories to the potential that exists within students both religious and academic. The boarding school MAN 3 promises a balanced education between physical and mental, spiritual and spiritual needs
\end{abstract}

Keywords-Character education, Boarding School, Religious, Independent

\section{INTRODUCTION}

Globalization is a phenomenon that occurs in the life in which humanity enters all aspects of life that are no longer separated. Globalization has led to good competition through the quality of a country or competition from the quality of its own population. In this situation, the state or nation can compete with the outside world, one of the ways the state must meet in order to compete with the global world by improving the quality of the community or its citizens. The improvement of human quality must necessarily be carried out in order to achieve the desire to compete in the current global era.

Advances in technology are a sign of the development process of globalization. It is said that technology is a driving force in various areas of world development, for in today's life everything has been controlled by various modern technologies, social, economic, cultural and political lives, which have been influenced by evolving technologies. The assumption that globalization is a foreign word is no longer valid today because globalization has influenced every human activity in terms of lifestyle, diet or clothing, it can be said that globalization has now touched all the important aspects of life.

Human quality, or often as Human Resources (HR) in the life of the world as it is now, increasingly making the belief that human quality must be obsessed because of the continuity of life in a demanding era like now. The quality of human resources is essentially related to the skills, abilities and working abilities of a person performing various activities to produce goods and services involved in determining the quality of life [1]. The increasing competition between people in the global era like today. High-quality human resources are one of the most important assets in the development of the Indonesian nation to survive during the complexity of the times. One way to improve the quality of human resources is through education.

The world of education is a place where the government carries out quality improvements and as a place to create high quality people that ensure the survival of a nation's life. National education has a strong foundation for the quality or quality of the nation's children. National education is an effort made by the government to educate the life of the nation. National education is a frame of reference translated into educational goals [2]. Indonesia implements the Law on National Education, which was included in Article 1 paragraph 5 of 2003, in terms of national education is education based on Pancasila and the Constitution of 1945 and changes that have their origins in religious teachings, Indonesian cultural diversity and responsiveness on the change of time, the national The education system must generate religious skills among the students, as required by the first pillar of Pancasila, which must guide the understanding of the other four pillars [3]

National education has the objectives set out in Article 3 of the National Education Act. The goal of the national education system is to develop the potential of students to become faithful people and to believe in God, the Almighty, noble, healthy, knowledgeable, capable, creative, independent, independent and democratic citizens. The purpose of national education itself is a role model for various elements of formal education providers. National education in the implementation of the goals of national education itself refers to the four pillars that 
were proclaimed by UNESCO. These four pillars are a vision of education in the present and future and must be developed by every educational institution. The four pillars are: (1) learning to learn, (2) learning (learning), (3) learning (being somebody), and (4) learning to live together (learning, to live together) [4].The purpose of national education is achieved through the influence of various components, namely the environment, infrastructure, resources and society, which must work together to achieve the goals of national education.

Madrasah Aliyah Negeri (MAN) 3 Palembang has officially founded schools that have established boarding schools since 2007. In previous years boarding schools or boarding schools were in this school, but not all students in a dormitory, since 2007 then all students Who wants to go to school in MAN 3 Palembang must enter the dormitory for one year. The obligation to undergo training on boarding is new students, new students who want to grow up and are currently completing junior high school.

Based on observations in schools implementing the boarding school, an adjustment process that confronted students with things they did not normally did not exclude the possibility of students who were willing to live in the dorm. The students were from a middle school that already lived or studied in a dorm. As it is known, the formation of this boarding school requires that students stay in dormitories and follow the rules of the hostel of MAN 3 Palembang. The dormitory is a place where students are endowed with religious knowledge and indirectly shape the character of the students to become better people and better prepared for the challenges of the global world

\section{BOARDING SCHOOL AND CHARACTER EDUCATION}

\section{A. Boarding School}

Boarding School comes from two words that have meaning, namely boarding and school. Boarding can be interpreted as boarding or boarding, while the school itself means school. For example, the boarding school can be defined as a boarding school or boarding school and is a special place of education where students study and live in the hermitage or dormitory [5]. In a broader sense, the boarding school is a fulltime school, a school that has a full-day class from morning to evening and sleeps in a dormitory with teachers, clerics, or pastors.

Boarding School can also be interpreted as a boarding school system such as the traditional teaching system on the Indian mainland, Boarding School, which is basically the same as the Pesantren, but Boarding School is a modern pesantren education system [6]. The boarding school is interpreted as a small house or dorm, where students from different or similar regions come and learn the holy book of AlQur'an and other Islamic teachings together [7]. Boarding schools are interpreted as small houses where students come from different or similar regions who live inside and study together the Koran and other Islamic teachings. In general, the boarding school is a development of schools that have dormitories, in fact, since the education system is indeed widespread, the boarding school education is indeed more watching the development of their students, with the use of the boarding school. Education like this is similar to a military or monastic academy education system (convent, convent) in the sense that students who are experiencing a change in conditions there in the aggregate, this conditional change will usually occur when students enter the dormitory Not only the physical preparation of the dorm, but also the dormitory manager himself has prepared rules that will be applied in the education process as long as the students are in the dorm and the rules must be followed by all students [8].

The boarding school is one of the alternative education systems that are in high demand at the time and accepted in the world of education. The boarding school is an educational institution where students not only learn but also live and live together the institution, in the historical perspective Boarding School refers to the classic British Boarding School. The term boarding school in several different countries, for example in the Commonwealth with the term public school in the United Kingdom, is referred to as "colledge", in the United States as a private school and in Malaysia as a college [9].

The purpose of the boarding school is something that can bring success in the world of education, boarding certainly has the will or the goal to be achieved in order to realize the desired success in the context of students, educational tools and Own educational environment. Schools with residential programs also guarantee positive values for students and maintain interaction outside of school [10]. In theory, boarding will take students away from home, which will certainly have a positive impact if the school environment and home environment continues to correlate [11]. Education really takes students away from their lives or daily lives in a family environment, but that does not just mean breaking the relationship between the students and their families and their family environment to achieve the desired goals, the correlation between students and families cannot be decided only because it can exert internal pressure on the students themselves, students experience inner stress, of course, the goals achieved by the boarding school system become increasingly difficult.

\section{B. Character}

Character by character according to Simon Philips in the book character is a collection of values that lead to a system based on thought, attitudes, and behaviors [12]. Character is the nature or character possessed in a person, and it is usually already formed and is a character that has become a habit contained in that person every activity that is done in their daily life 
reflects the character of this person. According to Ya'qub in Darmiati Zuchdi,, characters are character, morality and ethics Moral words, derived from the Arabic "al-aklaq"[13], are the plural forms of "alkhuluq", manners, behavior or behavior Imam alGhazali stated that morality is a natural state embedded in the soul from which actions emerge easily and without the need for thought and reflection [14]. In Islamic disciplines There is nothing that is separate from Islamic ethics. There are three main values that form the pillars of character building in Islam: morality, manners, and example. Moral refers to responsibilities and duties, $a d a b$ refers to attitudes that behave well while example refers to the quality of the character of a good Muslim, following the example of the Prophet Muhammad [15].

Character Values, Vale're value in Latin, which holds a meaning that is meaningful, will be empowered, and this value is seen as a good thing and has benefits for a group of people [16]. The character of the character in its development at this time has many meaning contents and values that have a positive influence on the personality of the students, character can be seen from the habits of the students, the basic values of character formation have seven main values for the structure of characters namely, honesty, responsibility, visionary, discipline, cooperation, justice and care [17]. Values that can be found in character formation itself are very closely related to the personality of the students themselves, the value of character formation is abstract, the values contained in character formation can also help to respect oneself and help not to bet about physical harm and morality [18].

In the late eighteenth century, it began to shift the formation of character into the world of education, and the character of this period also began by the German Peddor F. Foerster [19]. Where this character formation pursues several goals and is an education that aims to improve the quality of educational processes and outcomes that lead to the formation of character and noble character of students in a complete, integrated and balanced manner, in line with graduates -Competent standards. in every educational unit. The formation of the school / media culture is based on the values that underlie the behavior, the traditions and the daily habits, whereby the characteristics or school culture or medresse are also determined by the character of their pupils [20]. Explanation of character formation in a simple way can be interpreted as positive things by the teacher and this concerns the Winton students in [21]. Character formation is a conscious and serious effort by a teacher to teach values to the students. On the other hand, the application of character formation must be included in some aspects of (cognitive) knowledge. Emotions (feelings) and actions (actions).

According to Thomas Lickona in [22] without these three aspects, the character formation process will be less effective. [23] Character formation is a science that has branches and will continue to grow. Developing knowledge about character formation is something that cannot be achieved quickly, and it will not be easy to measure it. Stamina, motivation and resilience of a teacher are usually in high demand [24].

\section{METHODOLOGY}

The type of research in this study is qualitative research. This study aims to conduct an in-depth study on the application of character building in boarding schools in MAN 3 Palembang to generate wellorganized and complete information. Qualitative research method (qualitative research) is a research that aims to describe and analyze phenomena, events, social activities, attitudes, beliefs, perceptions, thoughts of individuals individually or in groups. Qualitative research has two main goals, namely, to describe and uncover (describe and research) and, secondly, to describe and explain (to describe and explain) [25].

The research site was conducted at MAN 3 Palembang, Jalan Inspector Marzuki No. 1, Siring Agung, Ilir Barat 1 Palembang City, South Sumatra. This research will be conducted in May 2018 - August 2018. Data collection techniques include (1) observation used to collect data by conducting observations on activities that are in the dorm, (2) interviews are structured interviews, documentation is used to obtain relevant data and to write written objects such as books, magazines, documents, regulations, minutes of meetings, diaries, etc. to examine. The informants in this study were the dorm leader, the dorm leader, two dormitories and 10 dormitory students in Class X and XI

The validity of the data in this study was performed using triangulation techniques. The triangulation technique that the researcher uses with source triangulation compares the degree of confidence of one informant with several other sources [26]. Triangulation techniques for testing data reliability are performed in several ways, but the source remains the same. The data analysis techniques used (1), field notes, are the phases of collecting all records or raw data and cannot be used for particular data classification categories. (2) data reduction, the process of selection of raw and raw data continuously throughout the study, (3) data presentation, the stage of organizing data in certain categories data presentation is done in a coherent and good manner in a narrative form be easy to understand, (4) verification data, steps taken to see the truth of the results of the analysis and to obtain a conclusion that can be trusted [27].

\section{IV.RESULT AND DISCUSSION}

Based on the research data, it is known that MAN 3 Palembang has a special program to promote the character of students in order to reach young people with high morale, therefore, MAN 3 Palembang offers a boarding school program to guide the students' 
Independent Development Program and Religious Development Program.

The coaching, independence and religion of this program are arranged and determined from the dormitory according to needs, which means that the program is flexible as it can change depending on the situation and condition of the school and students. The program is not included in the curriculum, both within the curriculum and out of school, and is not an issue. Instead, this program will be completely handed over to the hostel, but this will allow the school a smooth learning process.

MAN 3 Palembang with a boarding school provides habituation in everyday life to teach the students the value of independence. Activities like these are always carried out in daily life, starting with the dormitory activities, learning and returning to the dormitory. Boarders 'activities are beginning to get used to building students' independence in meeting their own needs. The habituation to the development of the independence of the students is achieved by observation, questioning and documentation. From the results of interviews with the head of the dormitory, students are used to managing personal needs independently. The activity was proved by getting used to washing their own clothes.

MAN 3 Palembang has written rules for the implementation of independence education activities to create a conducive atmosphere in the dormitories and to support the success of the implementation of independence character training. This was included in the guide to the implementation of the rules and regulations for students, namely dormitories to improve the quality of education in MAN 3 Palembang with the intention to train discipline, independence and the ability to improve religious and linguistic practices. Creating an Encouraging Dormitory Environment to Support the Characterization of the Discipline [27].

MAN 3 Palembang Dormitory Religious Coaching Program explained that the school is a formal educational institution that gives students appreciation, excellence, achievements in science and technology and IMTAQ, and environmental sustainability. The development of the training is supported by the management of a boarding school. In this boarding training system, MAN 3 Palembang provides students with dorm rooms to develop the potential that exists in both religious and academic disciplines.

Several parties are involved in preparing the religious program in the dormitory of the MAN 3 Palembang: the headmaster, the deputy head of the curriculum, the head of the care of men and daughters and the trainers. The planning of the program starts with the problems that arise both in the school and in the religious communities. With the emergence of these problems, clergy or coaches perform meetings to find solutions and implement work programs for dormitories, planning according through the process of
(1) defining planning, (2) analyzing educational problems, ( 3) to design and design plans, (4) to evaluate plans, (5) to specify plans, (6) implementation plans, (7) to monitor the implementation of plans and planners[28].

Conducting religious coaching programs in the dormitory is done in conjunction with the coach, or is often referred to as a cleric, in which each cleric directs and directs the students according to the goals in accordance with the terms, and the clergy / mentors perform their duties Memorization leads to the verses of the Qur'an and leads learners to repeat the memorization they already have. that two approaches are used in one coaching, the first is the direct approach and the second is the indirect approach. Direct coaching occurs when face-to-face interaction occurs between the supervisor and the supervised party. This indirect approach occurs when the coaches strive to promote those promoted through mass media such as written instructions, correspondence, bulletin dissemination and electronic media such as radio, cassettes and the Internet [29].

Supportive facilities received by students in the implementation of character building in religion in the MAN 3 Palembang dormitory are just one place often used to conduct religious programs such as dormitories, as well as lobbies and neighborhoods around dormitories, Muslims became known the excellence of the school based on boarding or boarding in addition to good programs, quality teachers, conducive environment, Heterogen learners as well as safety guarantees and quality assurance and complete facilities, of course, with complete facilities, students will learn more easily and can learn comfortably and well [26]. Of course, the results will be satisfactory.

Religious activities performed by students can bring about many changes, of course, the changes that are perceived by the students involve a considerable amount of change in the Aklak and changes in religious achievement. Changes in the students' morality are reflected in their behavior towards their peers, even towards their parents. While changes in religious achievement are usually received by students, namely the ability to read the Qur'an, I notice the Qur'an and the religious knowledge that increases after entering the dormitory.

Dormitory education in fact brings good impact on students in daily life and religious knowledge Education in dormitory can also take care of children from adverse environmental conditions, as well as grow children in a good environment in the supervision of mentors and friends, which can help enthusiasm in the Promote the implementation of teaching and learning activities. Economically speaking, education in dormitories requires higher fees than in normal schools, since the facilities offered, and the environment are better than the schools in general. In addition, students' religious activities are better and 
more targeted than other public schools. The boarding school MAN 3 promises a balanced education between physical and mental, spiritual and spiritual needs. Hopefully, there will be strong students who are secular in knowledge and technology and who are ready in faith and righteous actions.

\section{CONCLUSION}

The character building in the MAN 3 Palembang dormitory has long been implemented, and the concept of using the right character formation has been used in this dormitory to teach students independence, among other things. Independence character formation is done through habituation activities, this will be done from the dormitory 3 in Palembang to achieve optimal community education as expected. The independence program is followed by a more religious character improvement aimed at supporting the school's vision and mission, and boarding-school character management is a wise choice for overcoming moral decadence, especially teenagers. Character-oriented boarding school is an alternative for parents whose activities are solid and there is no time to teach their children.

\section{REFERENCES}

1] Ruhana, Ika. Pengembangan kualitas sumber daya manusia vs daya saing global. Jurnal Profit, Volume 6, 2012, pp. 50-56. http://www.ejournalfia.ub.ac.id/index.php/profit/article/view File/134/348

[2] Arikunto, Suharsimi. Dasar-dasar Evaluasi Pendidikan. Jakarta: PT. Bina Aksara, 1989.

[3] Saefur, Rohmat. Kurikulum dan Religious skill, 2017. http://eprints.uny.ac.id/id/eprint/46220

[4] Triyanto.E, Anitah.S. Peran Kepemimpinan Kepala Sekolah dalam Pemanfaatan Media Pembelajaran Sebagai Upaya Peningkatan Kualitas Proses Pembelajaran. Jurnal Teknologi Pendidikan. Vol. 1, No. 2, 2013, pp. 226-238. https://eprints.uns.ac.id/1754/1/187-346-1-SM.pdf

[5] Sulistiyono, S.T, Pendidikan karakter kaffah melalui pengembangan boarding school sebuah alternatif. Jurnal Agastya Vol. 5 No. 2, 2015, pp. 1-26. http://ejournal.unipma.ac.id/index.php/JA/article/view/884

[6] Musiran, Muh. Tesis Model Pembelajaran Al-islam dengan sistem Boarding School. Semarang: IAIN Walisongo Semarang, 2012.

[7] Efrizal, D. Improving Students' Speaking through Communicative Language Teaching Method at Mts Ja-alhaq, Sentot Ali Basa Islamic Boarding School of Bengkulu, Indonesia. International Journal of Humanities and Social $\begin{array}{llllll}\text { Science. } & \text { Vol. } & 2 & \text { No. } & 20, & 2012 .\end{array}$ http://www.ijhssnet.com/journal/index/1362

[8] Wahid, Abdurrahman. Menggerakkan Tradisi: Esai-esai Pesantren. Yogyakarta: LKiS, 2010.

[9] Maskudin. Pendidikan Islam aternatif menbangun karakter melalui sistem boarding school. Yogyakarta: UNY Press, 2013.

[10] Qomar, Mujamil. Pesantren dari Transformasi Metodologi Menuju Demokratisasi Institusi. Jakarta: Erlangga, 2007.

[11] Curto,V.E., \& Fryer Jr, R.G. The Potential of Urban Boarding Schools for the Poor: Evidence from SEED. Journal of Labor Economics, Vol. 32, No. 1, 2014, pp. 65-93 http://www.journals.uchicago.edu/doi/pdfplus/10.1086/6717 98

[12] Mu'in, Fathul. pendidikan karakter konstruksi Teoritik dan Praktik. Yogyakarta: Ar-Ruzz Media, 2011
[13] Zuchdi, darmiati, Pendidikan Karakter, Yogyakarta: UNY Press, 2015.

[14] Abdul, M. Dian, A. Pendidikan Karakter prespektif Islam. Bandung: PT Remaja Rosdakarya Offset, 2013

[15] Adisusilo,S.J.R. Pembelajaran nilai-nilai Karakter: konstuktivisme dan VCT sebagai inovasi pendekatan pembelajaran afektif. Jakarta: PT. Rajagrafindo Persada, 2013.

[16] Zuchdi, darmiati, Dkk. Pendidikan Karakter, Yogyakarta: UNY Pres, 2012

[17] Lickona, Thomas. Pendidikan Karakter: panduan lengkap mendidik siswa menjadi pintar dan baik, (Terjemahan Lita S). Bandung: Nusa Media. (Edisi Asli diterbitkan tahun 2008 oleh Bantam Book. New York, 2013.

[18] Koesoma, Doni. Pendidikan Karakter: Strategi Mendidik Anak di Zaman Modern Jakarta: PT. Grasindo, 2007.

[19] H.E. Mulyasa. Manajemen pendidikan karakter. Jakarta: Bumi aksara, 2013.

[20] Muchlas, Samani \& Hariyanto. Konsep dan Model: Pendidikan Karakter. Bandung: PT Remaja Rosdakarya, 2013.

[21] Azzet, A. M., Urgensi Pendidikan Karakter di Indonesia. Yogyakarta: Ar-Ruzz Media, 2011.

[22] Pattaro, Chiara. Character Education: Themes and Researches. An Academic Literature Review. Italian Journal of Sociology of Education. 8(1), 2016, pp. 6-30. doi: 10.14658/pupj-ijse-2016-1-2

[23] Milson.A.J., \& Mehlig.L.M. Elementary School Teachers' Sense of Efficacy for Character Education: The Journal of Educational Research, 96:1, 2010, pp. 47-53, DOI: 10.1080/0022067020959879.http://dx.doi.org/10.1080/0022 0670209598790

[24] Nana Syaodih Sukmadinata. Metode Penelitian Pendidikan. Bandung: Remaja Rosdakarya, 2008.

[25] Lexy J. Moleong. Metodologi Penelitian Kualitatif. Bandung: PT Remaja Rosdakarya, 2006.

[26] Sugiyono. Metode Penelitian Pendidikan Pendekatan Kuantitatif, kualitatif, dan R\&D. Bandung: Alfabeta, 2010.

[27] Berry, R. S., 100 Ideas that Work Disciplinein the Classroom. Philipines: ACSI Publications, 1994.

[28] Sudjana. Manajemen Program Pendidikan untuk Pendidikan Nonformal dan Pengembangan Sumber Daya Manusia. Bandung: Falah Prodution, 2010/

[29] Muslimin, S. Problem dan Solusi Pendidikan Sekolah Berasrama (Boarding School), 2008 
